\title{
M. Victoria Escandell Vidal, Manuel Leonetti, Cristina Sánchez López (eds.): 60 problemas de gramática. Dedicados a Ignacio Bosque
}

\author{
Madrid: Akal, 2011, 432 strani
}

Monografija 60 problemas de gramática je zasnovana kot poklon znanemu španskemu jezikoslovcu in akademiku, od leta 2011 tudi članu Evropske znanstvene akademije, Ignaciu Bosqueju ob njegovem šestdesetem rojstnem dnevu. Delo, ki ga je sooblikovalo 85 mednarodno uveljavljenih jezikoslovcev, med njimi so Bosquejevi učenci, kolegi in sodelavci, je poglobljena študija nekaterih perečih slovničnih problemov španskega jezika. Vsak prispevek se začne s predstavitvijo problema, na katerega je ob drugi priložnosti že opozoril Bosque, in tako vzpostavlja medbesedilni dialog z njegovimi predhodnimi deli, predvsem pa $\mathrm{z}$ dvema pomembnima publikacijama, ki sta izšli leta 2009: Novo špansko slovnico Kraljeve akademije (Nueva Gramática Española de Real Academia) in Temelji formalne sintakse (Fundamentos de sintaxis formal). Še posebej velja izpostaviti prvo, pri kateri je Ignacio Bosque sodeloval kot glavni urednik in predstavlja dolgo pričakovano normativno delo Znanstvene akademije za jezik (prejšnja izdaja je bila iz leta 1931), saj gre za prvo akademsko slovnico, ki predstavi vse različice evropske in ameriške španščine ter je rezultat intenzivnega sodelovanja vseh dvaindvajsetih akademij za španski jezik.

Monografija 60 problemas de gramática ni zgolj še eno izmed obsežnih in monotonih del, katerih vloga je predvsem poklon pomembni osebnosti in ki jih (tudi) $\mathrm{v}$ španskem prostoru ne manjka. Glavni namen tega dela je drugačen: monografijo sestavlja natanko 60 krajših prispevkov (zaradi že omenjene šestdesetletnice slavljenca), pri čemer vsak izmed njih izpostavlja konkreten slovnični problem španskega jezika, ki je izhodišče za jezikoslovno raziskovanje. Rezultat je homogeno in natančno artikulirano besedilo, zasnovano kot sklop problemov in rešitev, ki bo zadovoljilo tako zahtevnega bralca kot tudi tiste, ki se s španskim jezikom znanstveno ne ukvarjajo.

Delo je razdeljeno na dvanajst tematskih sklopov, na koncu je dodano analitično kazalo. Vsak prispevek se začne s kratko izpostavitvijo problema, ki je od ostalega 
besedila tudi tipografsko ločena. Nato sledita teoretski pretres in razlaga, na koncu pa so izpostavljena odprta mesta in možnosti za nadaljnje raziskave.

Prvi sklop, Categorías gramaticales, sestavljajo štirje prispevki. Ángel J. Gallego (Univerza v Barceloni) predstavi problem unitarne opredelitve prislova in veznika cuando ter izpostavi njegovo dvojno in celo asimetrično naravo. Isabel Pérez Jiménez (Inštitut CSIC) in Norberto Moreno Quibén (Univerza Castilla-La Mancha) proučujeta skladenjske lastnosti veznikov excepto, salvo in menos. Ángel Alonso-Cortés (Univerza Complutense v Madridu) predlaga kategorizacijo vzkličnice ojalá na podlagi sintaktičnih argumentov. José Camacho (Univerza Rutgers v New Jerseyju) raziskuje hkratno pojavitev veznika que in prislova como v nekaterih anomalnih strukturah.

Drugi sklop, Determinantes y cuantificadores, ki obravnava problematiko pridevniških in samostalniških zaimkov, sestoji iz osmih prispevkov. Luis Eguren (Univerza Autónoma v Madridu) raziskuje vzroke za specifiko nekaterih nedoločnih zaimkov v partitivnih strukturah. Helena López Palma (Univerza da Coruña) razmišlja o vlogi sintagem la mayoría in un ochenta por ciento pri izbiri določnega ali nedoločnega člena. María Luisa Rivero (Univerza v Ottawi) proučuje skladenjsko vlogo nedoločnega cualquiera pred in za samostalnikom. Edita Gutiérrez Rodríguez (Univerza Nacional a Distancia) izpostavi primere, ko nedoločna zaimka otro in demás nista zamenljiva. Bruno Camus Bergareche in Raquel González Rodríguez (Univerza Castilla-La Mancha) raziskujeta distribucijo nedoločnega zaimka otros v kombinaciji z muchos/pocos in bastantes/demasiados, medtem ko María Jesús Fernández Leborans in Cristina Sánchez López (Univerza v Madridu) pokažeta različne interpretacije nedoločnega mucho v povezavi zglagolskimi zvezami. Laura Brugè (Univerza Ca'Foscari v Benetkah) izpostavi raznolike vloge pridevniško rabljenih kazalnih zaimkov glede na njihov položaj v stavku. V zadnjem prispevku tega sklopa Xavier Villalba (Univerza Autònoma v Barceloni) raziskuje raznolike okoliščine samostalniških rab pridevnikov s členom za srednji spol.

V tretjem sklopu, Estructuras copulativas y predicación, so štirje prispevki. María J. Arche (Univerza v Greenwichu) raziskuje vpliv povedkovega določila na naravo atributivnih stavkov. Karen Zagona in Heles Contreras (Univerza Washington v Seattlu) proučujeta nekompatibilnost glagola ser s pridevniki, ki jim sledi določilo, medtem ko Yuko Morimoto in M. ${ }^{a}$ Victoria Pavón Lucero (Univerza Carlos III v Madridu) raziskujeta rabe glagolov hacerse in volverse kot pomensko nepopolnih. Luis Sáez (Univerza v Madridu) problematizira položaj osebka v povedkih z glagoli domnevanja.

Četrti sklop, Construcciones y estructura argumental, sestavlja devet prispevkov. Juan Carlos Moreno Cabrera (Univerza Autónoma v Madridu) proučuje nekatere 
omejitve pri rabi krajevnih prislovnih določil, Amaya Mendikoetxea ( $\mathrm{z}$ iste univerze) pa raziskuje različne rabe španskega dajalnika. Elena de Miguel ( $z$ iste univerze) izpostavi značilnosti glagolov, ki so lahko v nekaterih sobesedilih polnopomenski, v drugih pa pomensko nepopolni. Esther Torrego (Univerza Massachusetts v Bostonu) raziskuje izmuzljivost strukture hacer + infinitivo natančnejši opredelitvi. M. Teresa Espinal (Univerza Autònoma v Barceloni) in Louise McNally (Univerza Pompeu Fabra) proučujeta rabo krajevnih modifikatorjev pri samostalnikih brez določevalnih členov ali zaimkov. Angela Di Tullio (Univerza Nacional del Comahue) in Avellina Suñer (Univerza iz Girone) raziskujeta tako imenovane "gole pridevnike«, ki lahko nadomeščajo prislove, in nedoločne samostalniške zveze. Manuel Pérez Saldanya (Univerza v Valencii), Gemma Rigau (Univerza Autònoma v Barceloni) in Joan Solà (Univerza Barcelona) raziskujejo sintaktične razlike med sintagmama cuello abajo in boca arriba. Jan Schroten (Univerza v Utrechtu) analizira zunanjo vlogo osebka $\mathrm{v}$ različnih neosebnih strukturah, medtem ko Anna Bartra in M. Carme Picallo (Univerza Autònoma v Barceloni) poskusita odgovoriti na vprašanje, opiraje se na Chomskega, ali obstaja t. i. medslovnična kompetenca.

$\mathrm{V}$ petem delu, Aspecto, so trije prispevki posvečeni glagolskemu vidu. Luis García Fernández (Univerza Complutense v Madridu) raziskuje aspektualne vrednosti povratnoosebnega zaimka se, María José Rodríguez-Espiñeira in Jesús Pena (Univerza Santiago de Compostela) aspektualni kontrast med nedoločnikom in preteklim deležnikom, Ángeles Carrasco Gutiérrez (Univerza Castilla-La Mancha) pa se osredotoči na aspektualno specifiko nedoločnika.

V šestem sklopu, Indicativo y subjuntivo, je izpostavljena naklonska problematika, sestavljajo ga trije prispevki. Emilio Ridruejo (Univerza v Valladolidu) raziskuje razliko med indikativom in subjunktivom, ko se $\mathrm{v}$ prilastkovih odvisnikih pojavi presežnik. Guillermo Rojo (Univerza Santiago de Compostela) izpostavi enakosti in razlike med naklonskimi in časovnimi vrednostmi dveh oblik španskega imperfekta subjunktiva (cantara in cantase), težko razložljivimi znotraj strogih slovničnih okvirov. Ana Bravo (Univerza v Murcii) in Brenda Laca (Univerza Pariz 8) analizirata nekatere problematične rabe naklona $\mathrm{v}$ glagolski perifrazi ir $a+$ infinitivo $\mathrm{v}$ predmetnih odvisnikih.

Sedmi sklop, Negación, je posvečen problemu zanikanja, sestavlja pa ga pet prispevkov. Itziar Laka (Univerza País Vasco) in Josep Quer (Univerza Pompeu Fabra) raziskujeta paradoks zaimka nada, ki v določenih primerih omogoča dvojno branje. Ricardo Etxepare (Znanstveni inštitut Ikerbasque) in Myriam Uribe-Etxebarria (Univerza País Vasco) proučujeta mestoma nenavadno distribucijo zanikanih stavčnih členov. Javier Gutiérrez-Rexach (Univerza Ohio State) predstavi skladenjske 
in semantične omejitve rab nada más, nadie más in más nada in más nadie, Marina Fernández Lagunilla (Univerza Autónoma $\mathrm{v}$ Madridu) pa razišče razlike med zanikanjem s strukturo sin + infinitivo ter s strukturo no + gerundio. M. Victoria Escandell Vidal (UNED) in Manuel Leonetti (Univerza Alcalá) pokažeta na tesno povezanost med zanikanjem in besednim redom $\mathrm{v}$ stavku.

Osmi sklop, Coordinación y subordinación, obravnava večstavčne povedi, prav tako ga sestavlja pet prispevkov. M. Lluïsa Hernanz (Univerza Autònoma v Barceloni) raziskuje implicitne odvisnike $\mathrm{z}$ nedoločnikom, medtem ko Carlos Piera (Univerza Autónoma v Madridu) obravnava nekatere posebnosti odvisnega govora $\mathrm{z}$ glagolom decir. Julio Borrego (Univerza v Salamanki) izpostavi priredne in podredne odnose, ki jih lahko vzpostavljajo nestavčne povedi, in razišče kontekste, v katerih se pojavljajo. José A. Martínez in drugi (Univerza v Oviedu) raziskujejo različno distribucijo elementov v primerjalnih stavkih, medtem ko Ángeles Romero Cambrón (Univerza Castilla-La Mancha) proučuje zgradbo primerjalnih stavkov, ki izražajo neenakost.

Deveti sklop, Oraciones relativas e interrogativas, ki obravnava oziralne odvisnike in vprašalne stavke, sestavljajo štirje prispevki. José Francisco Val Álvaro in José Luis Mendívil Giró (Univerza v Zaragozi) proučujeta ujemanje osebe v oziralnih odvisnikih z osebnim zaimkom v glavnem stavku, medtem ko J. M. Brucart (Univerza Autònoma v Barceloni) raziskuje neujemanje v številu v oziralnih odvisnikih. Pascual José Masullo (Univerza Río Negro v Barrilocheju) izpostavi nekatere dvoumne primere oziralnih in vprašalnih zaimkov ter problem postavljanja grafičnega akcenta. Claudia Borgonovo (Univerza Laval) raziskuje razloge za dvojno interpretacijo besedne zveze no sabemos cómo: bodisi kot vprašalni odvisnik bodisi kot prislovno določilo načina.

Deseti sklop, Significado y combinatoria léxica, je posvečen pomenu in leksikalni kombinatoriki. Sestavljajo ga trije prispevki. Concepción Maldonado González (Založba SM) raziskuje semantične jezikovne mreže in pravila leksikalnega kombiniranja, podobno tudi María Auxiliadora Barrios (Univerza Complutense v Madridu). Margarita Alonso Ramos (Univerza v Coruñi) poskuša odgovoriti na vprašanje, ali so preneseni pomeni res zgolj variante ene leksikografske opredelitve ali gre morda za več leksikalnih enot.

Enajsti sklop, Morfología, je posvečen oblikoslovju, sestavlja ga pet prispevkov. Théophile Ambadiang (Univerza Autónoma v Madridu) raziskuje relevantnost morfofonoloških sprememb pri fleksiji samostalnika. Francisco Aliaga García in Fernando Lázaro Mora (Univerza Complutense $v$ Madridu) se osredotočata na samostalniškeheteronime in ponekod problematično rabo slovnično nezaznamovanega moškega spola. Antonio Fábregas (Univerza v Tromsu), Irene Gil (Real Academia Española) in Soledad Varela (Univerza Autónoma v Madridu) raziskujejo primere, 
ko se zdi, da predpona kljub pravilu vpliva na kategorijo podstave. Leonardo Gómez Torrego (Inštitut CSIC) se ukvarja s problematiko zapisa in morfologijo nekaterih sestavljenih zvez in večdelnih podstav. Francisco Hernández Paricio (Univerza v Zaragozi) poskuša odgovoriti na vprašanje, ali gre pri različnih rabah sin + infinitivo pri prvem za predpono ali predlog.

V zadnjem, dvanajstem sklopu, Gramática y discurso, je izpostavljena povezanost slovnice in diskurza, sestavlja pa ga sedem prispevkov. Mercedes Sedano (Univerza Central v Venezueli) in Tomás Jiménez Juliá (Univerza Santiago de Compostela) raziskujeta razlike med samostalniškimi prilastki in drugimi strukturami z enako vlogo. Salvador Gutiérrez Ordóñez (Real Academia Española in Univerza v Leonu) raziskuje vpliv narave glagola v govornih dejanjih izrekanja. María Antonia Martín Zorraquino (Univerza v Zaragozi) analizira dvojno naravo prislova igual, posebej njegovo rabo kot izražanja možne uresničitve dejanja. José Portolés (Univerza Autónoma v Madridu) razišče figurativno rabo besedne zveze lejos de, Luis Flamenco García (Univerza Castilla-La Mancha) pa mnogostranskost veznika in povezovalca aunque. Christina Kostova (Inštitut Cervantes v Fezu) izpostavi razliko med naklonsko sestavino izreka in naklonsko sestavino izrekanja.

Delo zaključi prispevek Joaquína Garrida (Univerza Complutense v Madridu), ki odgovarja na vprašanje, kako se v besedilu medsebojno povezujejo osnovne diskurzivne enote in osnovne slovnične enote (stavki), ter poda opredelitev diskurzivnih enot kot različnih diskurzov, ki niso zgolj sekvence ali segmenti, temveč so vsak zase strukturirana enota.

60 problemas de gramática je nedvomno zanimivo in pomembno delo $\mathrm{s}$ področja španskega jezikoslovja, predvsem zaradi svoje strukturne zasnove. Gotovo bo spodbujalo študij in refleksijo o španskem jeziku ter hkrati odpiralo nove interpretativne poti. 